Full-text Available Online at

https://www.ajol.info/index.php/jasem

http://ww.bioline.org.br/ja
J. Appl. Sci. Environ. Manage.

Vol. 24 (9) 1625-1630 September 2020

\title{
Effect of Fermentation, Germination and Combined Germination-Fermentation Processing Methods on the Nutrient and Anti-nutrient Contents of Quality Protein Maize (QPM) Seeds
}

\author{
${ }^{* 1}$ ANAEMENE DI; ${ }^{2}$ FADUPIN, GT \\ ${ }^{*}$ Department of Chemical and Food Sciences, Bells University of Technology, Ota, Ogun State, Nigeria \\ ${ }^{2}$ Department of Human Nutrition, University of Ibadan, Ibadan, Oyo State, Nigeria \\ *Corresponding Author Email: dorisianaemene@gmail.com
}

\begin{abstract}
Cereals remain the major components of traditional complementary foods but possess antinutritional factors in addition to nutrients. High antinutrient content have been linked to poor quality complementary foods and high level of undernutrition among children less than two years. Hence, this study examined the effect of fermentation, germination and combined germination-fermentation processing methods on the nutrient and antinutrient contents of Quality Protein Maize (QPM). Maize seeds were fermented and germinated for 72 hours. A batch of the germinated seeds was further fermented for 24 and 48 hours separately. The raw and processed maize seeds were chemically analysed for proximate, mineral (calcium, iron and zinc) and antinutrient (phytate, tannin, oxalate, saponin, polyphenol and hemaglutinnin) composition. ANOVA was used to detect significant differences. Result showed that the crude protein content of raw QPM seeds increased significantly from $10.04 \%$ to $10.44 \%$ after fermentation while it decreased to $9.12 \%$ following germination ( 72 hours)-fermentation ( 48 hours). Crude fat content decreased significantly with the treatments $(4.70-3.20 \%)$. Calcium $(10.38-4.23 \mathrm{mg} / 100 \mathrm{~g})$ and iron $(3.70-1.90 \mathrm{mg} / 100 \mathrm{~g})$ contents decreased significantly with all the methods. Germination and combined germination-fermentation reduced more antinutrients in maize compared to fermentation. Fermented seeds had the least tannin $(28-27.5 \mathrm{mg} / 100 \mathrm{~g})$ and phytate $(967.5-828.5 \mathrm{mg} / 100 \mathrm{~g})$ reduction while the oxalate $(590-646 \mathrm{mg} / 100 \mathrm{~g})$, saponin $(425-545 \mathrm{mg} / 100 \mathrm{~g})$ and hemaglutinnin $(17.31-19.53 \mathrm{mg} / 100 \mathrm{~g})$ contents increased. Germination-fermentation ( 24 hours) decreased phytate content by $>90 \%$ and retained more iron ( 79 vs $61 \%$ ) and zinc ( 80 vs $74 \%$ ) than fermentation. Combined germination-fermentation ( 24 hours) was more effective in antinutrient reduction in Quality Protein Maize seeds.
\end{abstract}

DOI: https://dx.doi.org/10.4314/jasem.v24i9.21

Copyright: Copyright (C) 2020 Anaemene and Fadupin. This is an open access article distributed under the Creative Commons Attribution License (CCL), which permits unrestricted use, distribution, and reproduction in any medium, provided the original work is properly cited.

Dates: Received: 10 August 2020; Revised: 16 September 2020; Accepted: 22 September 2020

Keywords: Maize, complementary foods, antinutrients, processing

Traditional complementary foods, mostly cereal based are regarded as inadequate (Serem et al., 2010) because of poor energy and nutrient density as well as bulkiness (Michaelsen et al., 2003). Commercial complementary foods are expensive and beyond the reach of majority of mothers who depend on low cost food mixtures (Dewey, 2013). Numerous locally prepared complementary foods have been developed from various food groups which are believed to be superior to only cereal complementary food. However, locally formulated complementary food based on fermented cereal gruel still dominates because it is cheaper and perceived by mothers as easy to digest (Ibeanu and Okeke, 2001). Cereal remains a major component of complementary foods including commercial complementary foods. This implies that the quality of traditional complementary foods depends largely on the quality of the cereal used. Maize (Zea mays) is the most common cereal used in traditional complementary foods production in the developing countries (Ogunba, 2012; Temesgen, 2013). Nigeria is the largest African producer of maize with about 20 million tonnes (Udegbunem, 2019). Common maize has two major known flaws. It is low in protein quality as a result of low lysine and tryptophan. The protein content of maize is about $9 \mathrm{~g} / 100 \mathrm{~g}$ dry weight (FAO 1992). In view of the deficit, Quality Protein Maize (QPM), an improved variety with high lysine and tryptophan was developed in 2004 (Vasal, 2006). The bulkiness caused by gelatinization of starch in cereals during cooking is another problem. The increased viscosity would require more dilution with water thereby reducing the energy density of prepared meal (Michaelsen et al., 2003). Germination process and addition of amylase rich flours are some of the measures recommended to reduce the viscosity and bulkiness of cereal based gruels. The third salient issue is that cereals in addition to nutrients possess anti-nutritional properties which negatively affect the bioavailability of protein and micronutrients (Bora 2014; Tufa et al., 2016). Although anti-nutritional factors in cereals are lower than those in legumes, the high proportion of cereals in complementary food mix makes it considerable. 
Cereals contain anti-nutrients such as phytate, tannin, trypsin and chymotrypsin inhibitors, cyanide, saponin, polyphenols, oxalates among others (Bora, 2014). The level of anti-nutrients in foods largely depends on the ingredients used in the preparation and methods of processing. Phytic acid is abundant in the seed portion of maize while in cereals such as wheat and rice it is more in the aleurone layer (Abdoulaye et al., 2011). Monogastric animals and humans lack phytase required to metabolize phytate (Singh et al., 2011). Phytic acid binds some minerals and inhibits the digestive enzymes necessary for protein starch degradation (Gupta et al., 2015). Roos et al. (2013) reported that the phytate contents of plant-based complementary foods offered to children in the developing countries ranged from 68 to 1536 $\mathrm{mg} / 100 \mathrm{~g}$. Consumption of maize meals was also associated with reduced zinc absorption in children. Research has shown that processing methods such as soaking, boiling, germination and fermentation could reduce the level of antinutrients thereby improving nutritional qualities of produced complementary foods (Agostini et al., 2010). Combination of processing methods may be more effective in eliminating or reducing anti nutrients than single techniques (Inyang and Zakari, 2008). During fermentation and germination, inherent phytases are activated which degrade the phytates (Temesgen, 2013). Reduction of anti-nutritional factors in cereals is very important in the formulation of complementary foods to ensure nutrient bioavailability. Extensive research has been undertaken on methods of reducing anti-nutrient content of various cereals used for complementary food formulation. However, there is limited information on the effect of processing methods on the chemical composition of Quality Protein Maize. Hence, this work examined the effect of fermentation, germination and combined germination-fermentation methods on the nutrient and anti-nutrient contents of QPM.

\section{MATERIALS AND METHODS}

Study design and sample collection: The study was experimental in design. Quality protein maize (ART 98/SW6-OB) seeds, a white maize variety with improved lysine and tryptophan content were obtained from the Institute of Agriculture, Research and Training, Ibadan (IAR\&T), MOOR Plantation, Ibadan.

Production of fermented maize seeds flour: Two hundred grammes of white maize seeds were cleaned, washed and soaked in excess tepid water $(1: 3 \mathrm{w} / \mathrm{v})$ and allowed to ferment naturally for 72 hours at $28^{\circ} \mathrm{C}$ (Onweluzo and Nwabugwu, 2009). The fermented seeds were washed and oven-dried at $60^{\circ} \mathrm{C}$ for $19-22$ hours, partially milled, dehulled, milled and sieved with $450 \mu \mathrm{m}$ pore sieve to obtain fermented maize flour.

Production of germinated maize seeds flour: Two hundred grammes of white maize seeds were cleaned, soaked in excess tepid water for 24 hours (rinsed at 12th hour and 24th hour), washed and spread on moist jute bags. The maize seeds were washed, drained and spread again at 24th hour and 48th hour of germination and allowed to continue to sprout at room temperature till 72 hours using a modified method of Onweluzo and Nwabugwu (2009). Water was sprinkled once a day during the germination period to encourage aeration. Half of the sprouted seeds were oven-dried at $60^{\circ} \mathrm{C}$ for $18-21$ hours. The rootlets and hulls were removed and seeds were milled, sieved with a $450 \mu \mathrm{m}$ pore sieve and tagged as germinatedted maize flour.

Production of germinated fermented maize seeds flour: The remaining (half) of the sprouted maize seeds were divided into two and fermented separately in water $\left(28^{\circ} \mathrm{C}\right)$ for 24 and 48 hours. The sprouted fermented seeds were oven-dried at $60^{\circ} \mathrm{C}$ for $20-22$ hours, dehulled, milled and sieved with a $450 \mu \mathrm{m}$ pore sieve into sprouted fermented (24) and sprouted fermented (48) maize flour (2 products). The flours obtained were stored in Zip-lock bags $(26.5 \mathrm{~cm} \mathrm{x}$ $27.3 \mathrm{~cm}$, BJohnson) at $4^{\circ} \mathrm{C}$ for analysis.

Nutrient and antinutrient analysis: The moisture, fat, crude protein $(\mathrm{N} \times 6.25)$, crude fibre and ash contents of the raw and processed maize flour were determined in triplicates according to the approved procedures of the Association of Official Analytical Chemists (AOAC, 2005). The iron and zinc contents were determined using the atomic absorption spectrophotometer (Buck 200, Buck Scientific, USA), while calcium was determined using flame Jenway Digital Flame Photometer (PFP7, Bibby Scientific Limited, United Kingdom). The method of Onwuka (2005) was employed in the determination of oxalate while phytate, tannin, saponin and hemaglutinnin were determined by the method described by AOAC (2005).

\section{RESULTS AND DISCUSSION}

The row labeled Mo displays the proximate and mineral contents of raw white maize while the values after processing are displayed on the rows below it (Table 1). The table shows that the crude protein content of white maize $(10.04 \mathrm{~g} / 100 \mathrm{~g})$ increased significantly $(\mathrm{p}<0.05)$ after 72 hours of fermentation $(10.44 \mathrm{~g} / 100 \mathrm{~g})$, while it decreased significantly $(\mathrm{p}<0.05)$ to $9.12 \mathrm{~g} / 100 \mathrm{~g}(9.2 \%)$ when germinated (72 hours) and fermented for 48 hours continuously. The 
other treatment methods did not have significant effect $(\mathrm{p}>0.05)$ on the crude protein content of quality protein maize. Crude fat content of maize decreased significantly with all the treatments. The lowest value of fat $(3.20 \mathrm{~g} / 100 \mathrm{~g})$ was observed when the seeds were germinated for 72 hours. The ash content of maize was lowest $(0.99 \mathrm{~g} / 100 \mathrm{~g})$ when germinated-fermented for 48 hours. Carbohydrate composition of maize increased significantly $(\mathrm{p}<0.05)$, while calcium and iron content decreased significantly $(\mathrm{p}<0.05)$ with all the treatments (Table 2). Zinc contents decreased significantly $(\mathrm{p}<0.05)$ with all the treatments except for combined germination-fermentation for 48 hours where there was a slight insignificant increase $(0.3 \%)$. The effect of fermentation, germination and germination-fermentation on the anti-nutrient contents of maize is presented in Table 3 . It shows that the levels of phytate, oxalate, saponin, polyphenol and hemaglutinin reduced significantly $(\mathrm{p}<0.05)$ with germination and germination-fermentation methods. Germination and combined germination-fermentation methods were more effective in phytate reduction in maize $(>90 \%)$ compared to fermentation $(14 \%)$. The tannin contents of raw maize seeds reduced by only $1.8 \%$ when the seeds were fermented for 72 hours. Surprisingly, the oxalate, saponin and hemaglutinnin contents of maize increased with fermentation. Phytate levels decreased from $967.50 \mathrm{mg} / 100 \mathrm{~g}$ (control) to $828.50 \mathrm{mg} / 100 \mathrm{~g}$ (fermentation), $85.50 \mathrm{mg} / 100 \mathrm{~g}$ (germination), $74.50 \mathrm{mg} / 100 \mathrm{~g}$ (germination (72 hours)-fermentation (24 hours)) and $61.00 \mathrm{mg} / 100 \mathrm{~g}$ (germination (72 hours)-fermentation (48 hours)). In summary (Table 4), fermentation of maize reduced phytate content by $14 \%$, increased protein content by $4 \%$ and retained about $72 \%$ of calcium. Combined germination ( 72 hours)-fermentation ( 24 hours) of maize decreased phytate content of maize by more than $90 \%$ and retained more iron $(79 \%$ vs $61 \%)$ and zinc $(80 \%$ vs $74 \%)$ compared to fermentation. Germination although reduced above $90 \%$ phytate retained less calcium, iron and zinc.

Table 1. Proximate composition of fermented, germinated and germinated/fermented white maize flour (dry weight basis)

\begin{tabular}{|c|c|c|c|c|c|c|}
\hline & Moisture (\%) & $\begin{array}{l}\text { Crude protein } \\
(\%)\end{array}$ & $\begin{array}{l}\text { Crude fat } \\
\text { (\%) }\end{array}$ & $\begin{array}{l}\text { Crude fibre } \\
\text { (\%) }\end{array}$ & $\begin{array}{l}\text { Ash } \\
(\%)\end{array}$ & $\begin{array}{l}\text { CHO } \\
(\%)\end{array}$ \\
\hline $\mathrm{M}_{0}$ & $8.63^{x} \pm 0.02$ & $10.04^{b} \pm 0.06$ & $4.72^{2} \pm 0.02$ & $1.41^{b} \pm 0.03$ & $1.79^{2} \pm 0.02$ & $74.82^{4} \pm 0.08$ \\
\hline $\mathrm{M}_{1}$ & $7.33^{d} \pm 0.02$ & $10.44^{\mathrm{a}} \pm 0.13$ & $4.30^{\mathrm{h}} \pm 0.02$ & $1.18 \pm 0.02$ & $1.11^{4} \pm 0.01$ & $76.81^{\circ} \pm 0.12$ \\
\hline $\mathrm{M}_{2}$ & $7.43^{c}=$ & $10.04^{b} \pm 0.05$ & $3.20^{c} \pm 0.03$ & $1.20^{\circ} \pm 0.01$ & $1.49^{\prime} \pm 0.02$ & $77.84^{b} \pm 0.05$ \\
\hline${ }^{*} \mathrm{M}_{3}$ & $7.47^{2} \pm 0.02$ & $9.92^{\circ} \pm 0.13$ & $3.40^{4} \pm 0.02$ & $1.59^{4} \pm 0.02$ & $1.41^{c} \pm 0.02$ & $77.79^{\prime} \pm 0.14$ \\
\hline $\mathrm{M}_{4}$ & $7.74^{b} \pm 0.02$ & $9.12^{c} \pm 0.12$ & $3.80^{\circ} \pm 0.01$ & $1.19^{\circ} \pm 0.02$ & $0.99^{\varepsilon} \pm 0.01$ & $78.35^{\mathrm{a}} \pm 0.12$ \\
\hline
\end{tabular}

Values are expressed as mean $\pm S D(n=3)$. Means in the same column with different superscripts are significantly different from each other at $P<0.05 . M_{O}$ raw maize; $M_{1^{-}}$fermented maize (72h); $M_{2}$-germinated maize(72h); $M_{3^{-}}$germinated/fermented $(72 h / 24 h) ; M_{4-}$ germinated/fermented ( $72 \mathrm{~h} / 48 \mathrm{~h})$, CHO-carbohydrate

Table 2. Mineral composition of fermented, germinated and germinated/fermented white maize flour (dry weight basis)

\begin{tabular}{clll}
\hline $\begin{array}{l}\text { Calcium } \\
(\mathrm{mg} / 100 \mathrm{~g})\end{array}$ & $\begin{array}{l}\text { Iron } \\
(\mathrm{mg} / 100 \mathrm{~g})\end{array}$ & $\begin{array}{l}\text { Zinc } \\
(\mathrm{mg} / 100 \mathrm{~g})\end{array}$ \\
\hline $\mathrm{M}_{0}$ & $10.38^{\mathrm{a}} \pm 0.07$ & $3.70^{\mathrm{a}} \pm 0.53$ & $2.28^{\mathrm{a}} \pm 0.06$ \\
$\mathrm{M}_{1}$ & $7.05^{\mathrm{b}} \pm 0.14$ & $2.25^{\mathrm{bc}} \pm 0.35$ & $1.68^{\mathrm{c}} \pm 0.04$ \\
$\mathrm{M}_{2}$ & $4.35^{\mathrm{d}} \pm 0.07$ & $1.90^{\mathrm{c}} \pm 0.07$ & $1.60^{\mathrm{c}} \pm 0.07$ \\
${ }^{*} \mathrm{M}_{3}$ & $4.63^{\mathrm{c}} \pm 0.11$ & $2.93^{\mathrm{b}} \pm 0.11$ & $1.83^{\mathrm{b}} \pm 0.03$ \\
$\mathrm{M}_{4}$ & $4.23^{\mathrm{d}} \pm 0.07$ & $2.83^{\mathrm{b}} \pm 0.11$ & $2.38^{\mathrm{a}} \pm 0.01$ \\
\hline
\end{tabular}

Values are expressed as mean $\pm S D(n=3)$. Means in the same column with different superscripts are significantly different from each other at $P<0.05 . M_{O}$-raw maize; $M_{1^{-}}$fermented maize $(72 h) ; M_{2}$-germinated maize(72h); $M_{3^{-}}$germinated/fermented $(72 h / 24 h) ; M_{4^{-}}$ germinated/fermented $(72 \mathrm{~h} / 48 \mathrm{~h})$

Table 3. Anti-nutrient composition of fermented, germinated and germinated/fermented maize flour (dry weight basis)

\begin{tabular}{lllllll}
\hline Parameters & $\begin{array}{l}\text { Tannin } \\
(\mathrm{mg} / 100 \mathrm{~g})\end{array}$ & $\begin{array}{l}\text { Phytate } \\
(\mathrm{mg} / 100 \mathrm{~g})\end{array}$ & $\begin{array}{l}\text { Oxalate } \\
(\mathrm{mg} / 100 \mathrm{~g})\end{array}$ & $\begin{array}{l}\text { Saponin } \\
(\mathrm{mg} / 100 \mathrm{~g})\end{array}$ & $\begin{array}{l}\text { Polyphenol } \\
(\mathrm{mg} / 100 \mathrm{~g})\end{array}$ & $\begin{array}{l}\text { Hemaglutinin } \\
(\mathrm{HU} / 100 \mathrm{~g})\end{array}$ \\
\hline $\mathrm{M}_{\mathrm{O}}$ & $28.00^{\mathrm{a}} \pm 1.41$ & $967.50^{\mathrm{a}} \pm 10.61$ & $590.00^{\mathrm{a}} \pm 84.86$ & $425.00^{\mathrm{b}} \pm 49.50$ & $1110.00^{\mathrm{a}} \pm 56.57$ & $17.31^{\mathrm{b}} \pm 0.04$ \\
$\mathrm{M}_{1}$ & $27.50^{\mathrm{a}} \pm 4.95$ & $828.50^{\mathrm{b}} \pm 2.12$ & $646.00^{\mathrm{a}} \pm 5.66$ & $545.00^{\mathrm{a}} \pm 35.35$ & $715.00^{\mathrm{c}} \pm 35.36$ & $19.53^{\mathrm{a}} \pm 0.07$ \\
$\mathrm{M}_{2}$ & $20.00^{\mathrm{ab}} \pm 1.41$ & $85.50^{\mathrm{c}} \pm 2.12$ & $42.50^{\mathrm{b}} \pm 4.95$ & $195.00^{\mathrm{c}} \pm 21.21$ & $985.00^{\mathrm{b}} \pm 35.36$ & $13.65^{\mathrm{c}} \pm 0.04$ \\
$* * \mathrm{M}_{3}$ & $20.50^{\mathrm{ab}} \pm 4.95$ & $74.50^{\mathrm{cd}} \pm 4.95$ & $31.00^{\mathrm{b}} \pm 2.83$ & $140.00^{\mathrm{c}} \pm 14.14$ & $795.00^{\mathrm{c}} \pm 49.50$ & $9.18^{\mathrm{d}} \pm 0.04$ \\
$\mathrm{M}_{4}$ & $17.00^{\mathrm{b}} \pm 2.83$ & $61.00^{\mathrm{d}} \pm 1.41$ & $29.50^{\mathrm{b}} \pm 4.95$ & $135.00^{\mathrm{c}} \pm 35.35$ & $745.00^{\mathrm{c}} \pm 35.36$ & $8.83^{\mathrm{c}} \pm 0.05$ \\
\hline
\end{tabular}

Values are expressed as mean $\pm S D(n=2)$. Means in the same column with different superscripts are significantly different from each other at $P<0.05 . M_{O^{-}}$raw maize; $M_{1^{-}}$fermented maize (72h); $M_{2}$-germinated maize $(72 \mathrm{~h}) ; M_{3^{-}}$germinated/fermented $(72 \mathrm{~h} / 24 \mathrm{~h}) ; M_{4^{-}}$ germinated/fermented $(72 \mathrm{~h} / 48 \mathrm{~h})$

The crude protein values of raw and processed maize seeds ranged from $9.12-10.44 \%$. These values agreed closely with the values reported by Tufa et al. (2016) for maize (7.34-10.61\%). Fermentation increased the crude protein levels of maize as also observed by Tufa et al. (2016). In millet by Inyang and Zakari (2008) 
and in sorghum by Kinyua et al. (2016). The increase in protein level may be as a result of increased synthesis of certain amino acids by the fermenting seeds (Bora, 2014). Germination did not have any effect on the crude protein of maize $(10.04 \%)$, while combined germination and fermentation methods decreased the crude protein contents of quality protein maize from $10.04 \%$ to $9.92 \%$. This finding agrees with the report of Ikujenlola and Adurotoye (2014), but contrasted with the works of Inyang and Zakari (2008), and Kinyua et al. (2016). These researchers reported increase in crude protein contents of millet and sorghum with combined germinationfermentation and germination, respectively. The difference could be due to varietal and geographical variations as well as varying conditions of treatment and analysis. Total ash, iron, and zinc levels were reduced significantly in the maize flour with all the treatments. Similar results were reported by Ikujenlola and Adurotoye (2014) and Tufa et al. (2016). The loss in mineral content could be attributed to probable leaching of some volatile compounds to the fermenting medium and degradation of dry matter (Nnam and Obiakor, 2003). However, the losses were less in combined germinated-fermented maize. The reduced ash content for maize with fermentation did not agree with the finding of Mbaeyi-Nwaoha and Obetta (2016), who reported increased ash content of fermented millet flours. They also reported an increase in the zinc content of fermented millet while the iron level decreased. Carbohydrate content increased significantly $(p<0.05)$ from $74.82 \%$ (control) to $78.35 \%$ in combined germinated-fermented maize (72/48 hours). The increased carbohydrate levels observed in maize contrasted with several works mentioned above, which reported decreased levels of carbohydrate with fermentation and germination. This could be due to reduced moisture content of the treated samples when compared to control as a result of the drying process. Fermentation, germination and combined germination-fermentation (72/48 hours) significantly decreased the crude fibre and crude fat levels in maize while combined germinationfermentation (72/24 hours) increased the crude fibre level from $1.41 \%$ to $1.59 \%$. Ikujenlola and Adurotoye (2014) also observed reduction in the crude fibre of maize (5.08 to $4.51 \%$ ) with germination but increased fat levels (1.80 to $2.35 \%$ ), while Tufa et al. (2016) and Onweluzo and Nwabugwu (2009) reported increased fat levels of maize (4.35 to $4.70 \%)$ and millet (1.50 to $4.50 \%$ ), respectively after germination process. Change in fat levels may be as a result of the increased activities of lipolytic enzymes which hydrolyse fats to fatty acid and glycerol (Mbaeyi-Nwoha and Obetta, 2016).

\begin{tabular}{|c|c|c|c|}
\hline Processing methods & Increase & Decrease & No effect \\
\hline $\begin{array}{l}\text { Fermentation } \\
\text { maize }\end{array}$ & $\begin{array}{l}\text { Protein, fibre, } \\
\text { Calcium, carbohydrate }\end{array}$ & Fat, ash, iron, zinc, phytate (14\%) & \\
\hline $\begin{array}{l}\text { Germination } \\
\text { maize } \\
\text { GerFer }(72 / 24 \mathrm{hrs})\end{array}$ & Eibse, carbohydrate & Anti-nutrients, ash, iron, zinc & protein \\
\hline maize & Carbohydrate, fibre. & $\begin{array}{l}\text { Phytates ( }>90 \% \text { ), Protein(less), fat, ash, } \\
\text { iron (less), Calcium (less), zinc }\end{array}$ & \\
\hline GerFer (72/48hrs) Maize & Carbohydrate & $\begin{array}{l}\text { Calcium, Iron, zinc, fat, protein, fibre, } \\
\text { anti-nutrients }\end{array}$ & \\
\hline
\end{tabular}

Fermentation, germination, and combined germination-fermentation reduced the anti-nutrient contents of maize particularly phytate, tannin and oxalate contents (Tables 5). Similar findings were reported by several researchers including Kinyua et al. (2016) and Gbadamosi, et al. (2017). Germination of maize significantly reduced tannin, phytate, oxalate, polyphenol, and hemaglutinnin. However, the contents of ash, iron, and zinc were negatively affected. Combined germination (72hrs) -fermentation ( $24 \mathrm{hrs}$ ) in addition to reducing above $90 \%$ of phytate in maize, retained more nutrients. Increased period of germination (Agostini et al., 2010) resulted in more phytate reduction. This reduction has been attributed to the activities of endogenous and microbial phytases in the germinating and fermenting seeds, respectively.
Passive diffusion of water-soluble phytates could have contributed to the phytate reduction (Thompson and Amoroso, 2011). The natural lactic acid fermentation offers favourable $\mathrm{pH}$ conditions for the enzymatic degradation of phytates to organic phosphate, inositol, and other simpler forms. Germination and combined germination-fermentation methods were more effective in reducing the anti-nutrient content of maize compared to fermentation. High anti-nutrient content of foods is detrimental to health as it chelates vital minerals such as calcium, zinc, and iron including proteins to form complexes and make the unavailable.

Conclusion: Germination and combined germinationfermentation method reduces anti-nutrient content of maize compared to fermentation. More nutrients are 
retained in maize after combined germination (72 hours) -fermentation for 24 hours. Therefore, combined germination ( 72 hours)-fermentation ( 24 hours) is the preferred processing method for maize. Mothers should be enlightened on the combined germination-fermentation of cereals. This should be part of the dietary diversity campaign. However, measures to ensure micronutrient sufficiency in processed complementary food must be part of infant feeding enlightenment programmes.

\section{REFERENCES}

Abdoulaye, C; Brou, K; Jie, C (2011). Phytic acid in cereal grains: structure, healthy or harmful ways to reduce phytic acid in cereal grains and their effects on nutritional quality. Amer J. of Plant Nutr. Fertil. Technol. 1:1-22.

Agostini, JDS; Nogueira, RB; Ida, EI (2010). Lowering of phytic acid content by enhancement of phytase and acid phosphatase activities during sunflower germination. Braz. Arch. Bio. Technol. 53:975-980.

AOAC. (2005). Official methods of analysis of AOAC International; Horwitz W, eds. Gaithersburg, MD, Washington, DC, USA: AOAC International.

Bora, P (2014). Anti-nutritional factors in food and their effects. J. of Aca. Ind. Res. 3(6):285-290.

Dewey, KG (2013). The challenge of meeting nutrient needs of infants and young children during the period of complementary feeding: an evolutionary perspective. J. of Nutr. 108: 20502054.

FAO. (1992). Maize in Human Nutrition. Food and Agriculture Organization of the United Nations, Rome.

Gbadamosi, TR; Otitiola, OC; Akanfe, FA; Asimi, T; Bamisaye, F; Isola, OC (2017). Nutritional analysis of formulated complementary foods from selected Nigeria crops. Int. J. of Sci. Engi Environ. Technol. 2(10):69-75.

Gupta, RK (2015). Reduction of Phytic Acid and Enhancement of Bioavailable Micronutrient in Food Grains. J. of Food Sci. Technol. 52(2):676684.

Ibeanu, V; Okeke, EG (2001). Development and acceptability test of Amylase Rich Flour (ARF) enriched complementary foods. Nig. J. Nutr. Sci. 22: 13-19.
Vasal, SK (2006). Quality Protein Maize Story. Food Nutr. Bull. 21:445-450.

Ikujenlola, AV; Adurotoye, M (2014). Evaluation of quality characteristics of high nutrient dense complementary food from mixtures of malted quality maize and steamed cowpea. J. of Food Process. Technol. 5.1.

Inyang, CU; Zakari, UM (2008). Effect of germination and fermentation of pearl millet on proximate, chemical and sensory properties of instant Fura: A Nigerian cereal food. Pak. of J. Nutr. 7: 9-12.

Kinyua, PM; Mwasaru, MA; Onyango, CA; Muinga, R; Gathambiri, C (2016). Nutritional composition of Kenyan sorghum-pigeon pea instant complementary food. JAGST 17.1.

Mbaeyi-Nwaoha, IE; Obetta, FC (2016). Production and evaluation of nutrient-dense complementary food from millet (Pennisetum glaucum), pigeon pea (Cajanus cajan) and seedless breadfruit (Artocarpus altillis) leaf powder blends. Afr. J. of Food Sci. 10(9):143-156.

Michaelsen, KF; Weaver, L; Branca, F; Roberlson, A (2003). Feeding and nutrition of infants and young children: Guidelines for the WHO European region with emphasis on the former Soviet countries. WHO regional publications European series. No 87.

Ogunba, BO (2012). Adoption of enriched local complementary food in Osun state: Combating micronutrient deficiency in the first two years of life. Afr. Res. Rev. 6(1):171-182.

Onweluzo, JC; Nwabugwu, CC (2009). Fermentation of millet (Pennisetum americanum) and pigeon pea (Cajanus cajan) seeds for flour production: Effects on composition and selected functional properties. Pak. J. of Nutr. 8(6):737-744.

Onwuka, GI (2005). Food analysis and instrumentation; Theory and Practice. Naphthali prints. Lagos, Nigeria.

Roos, N; Sorensen, JC; Sorensen, H; Rasmussen, SK; Briend, A; Yang, ZY; Huffman, SL (2013). Screening for anti-nutritional compounds in complementary foods and products for infants and young children. $M C N$ 9(Suppl 1): 47-71.

Serrem, CA (2010). Development of soy fortified sorghum and bread wheat biscuits as a 
supplementary food to combat Protein Energy Malnutrition in young children. Thesis work, University of Pretoria, Pretoria, South Africa.

Singh, B; Kunle, G; Satyanaragana, T (2011). Developments in biochemical aspects and biotechnological application of microbial phytases. Biotech. Mole. Bio. Rev. 6:69-87.

Temesgen, M (2013). Nutritional status of Ethiopian weaning and complementary foods: A Review. Open Access Scientific Reports. 2(2): 621.
Thompson, B; Amoroso, L (2011). Combating micronutrient deficiency: Food based approaches. $\mathrm{FAO} / \mathrm{CAB}$ International.

Tufa, MA; Urga, K; Weledesemayat, GT; Mitiku, BG (2016). Development and nutritional assessment of complementary foods from fermented cereals and soybean. J. of Food Sci. Nutr. 2:014.

Udegbunem, O (2019). Nigerian maize production increases more than two fold between 2015 and 2018. Premium Times. April 3. 